\title{
Cecylia Kuta
}

ORCID: https://orcid.org/0000-0001-9485-3239

Historical Research Office of the Institute of National Remembrance, Krakow, Poland

\section{Mieczysław Kotlarczyk - a Teacher and Artistic Friend of John Paul II}

\begin{abstract}
Mieczysław Kotlarczyk played an important role in the life of Pope John Paul II. The spiritual bond between friends born in the same city exerted a significant impact on both their lives and work. And yet it remains unknown to the public, just as Kotlarczyk himself. Raised in a theatre-related family, Kotlarczyk remained affiliated with the theatre throughout his life. This paper presents his life path and the fate of the Rhapsodic Theatre, which Kotlarczyk was managing from 1941, and which operated under the auspices of the "Unia" ("Union") underground organization. After World War II, despite reprisals from the communist authorities and the subordination to thesecret service, Kotlarczyk tried to continue his activity. In 1953, the Rhapsodic Theatre was liquidated by the authorities. Even though in 1957, as part of the so-called thaw, there was a consent to reactivate the theatre, ten years later however, it was definitely shut down. Among those protesting against the decision, was Karol Wojtyła, the then Archbishop of Kraków.
\end{abstract}

\section{Keywords}

John Paul II, Karol Wojtyła, Mieczysław Kotlarczyk, Communism, communist secret service of the Polish People's Republic, Rhapsodic Theatre. 


\section{The beginning of thetheatre career}

When asked, who of the lay people exerted the greatest influence on his life, Pope John Paul II gave an answer: Jan Tyranowski and Mieczysław Kotlarczyk. He admitted that, in particular, the latter passed on to him much "from the riches of his soulwhich was in love with all that great legacy of literary and artistic culture, indigenous and Polish, as well as that of Europe and the world."' The story of the artistic friendship of the future Pope with Kotlarczyk gained the interest of researchers, especially following the publication, in 2001, of the "On the Rhapsodic Theatre" book, in which the letters of Karol Wojtyła to Kotlarczyk were published. A special, spiritual bond between the friends born in the same city, which exerted a significant impact on their lives and work, remains unknown to the world's public opinion, just like the creator of the Rhapsodic Theatre himself.'

Mieczysław Kotlarczyk was born on 6 May 1908 in Wadowice. He was one of five children of the court clerk Stefan Kotlarczyk and Maria née Malott. The Kotlarczyk family was distinguished and respected in a small-town environment. Stefan Kotlarczyk was the organizer of the local theatre activity, creator of the amateur theatre of the "Falcon" Polish Gymnastic Society, operating at the Town Reading Room, and founder of the King Władysław Jagiełło Association, popularly known as the "Jagiellonka."

Since he was a child, Mieczysław Kotlarczyk was affiliated with the theatre run by his father and inherited his love of the spoken word. Having graduated from high school and passed the leaving exams, he went on to study Polish Philology at the Jagiellonian University in Krakow. He graduated in 1931 with a master's degree in philosophy. Two years later, in 1933, having completing a pedagogical study, teaching practice at Wadowice-based schools (Coeducational Municipal

1 As cited in S. Kowalewski, Apostoł Żywego Słowa, „Niedziela” (2003), no 9.

${ }^{2}$ Authors writing about the friendship of Karol Wojtyła with Mieczysław Kotlarczyk: J. Popiel, Karol Wojtyła i Mieczysław Kotlarczyk. Historia artystycznej przyjaźni, „Ethos”, R. 20, no 1/2 (2007), pp. 269-282; T. Malak, Karol Wojtyła a Teatr Rapsodyczny, „Ethos”, R. 20, no 1/2 (2007), pp. 294-306.

${ }^{3}$ S. Dziedzic, Rapsodyczny "płaszcz niewyżebrany” Mieczysława Kotlarczyka, "AnnalesUniversitatisPaedagogicaeCracoviensis. Studia Historicolitteraria 12", Kraków 2012, p. 123; J. Kotlarczyk, D. Mróz, Stefan Kotlarczyk i jego teatr familijny, in: S. Kotlarczyk, ....Z doby dzisiejszej. Za Matkę Ojczyznę, Wadowice 2007, edited by Wadowickie Centrum Kultury im. Marcina Wadowity, p. 13-61. 
Trade School and the Private Gymnasium of the Order of Discalced Carmelites) and passing the state examination, he obtained a high school teacher's diploma. ${ }^{4}$ For the next two years, from 1933 to 1935, he was working in the Gymnasium of the Pallottine Fathersin Wadowice. In 1936, he obtained a doctorate in philosophy at the Jagiellonian University and began working at a gymnasium and general secondary school in Sosnowiec. ${ }^{5}$

Raised in a theatrical family, he already made his debut in his father's theatre as a child. Kotlarczyk was cast in at least five plays while still in elementary school and appeared in twenty performances in the gymnasium Dramatic Circle, as well as in the municipal and parish theatre. ${ }^{6}$ In the student years, he was the leader of the Dramatic Circle at the Wadowice Academic Circle, with whom he staged seven plays. ${ }^{7}$ Following his father's death in 1931, Kotlarczyk took over his theatre in Wadowice. He founded the new Amateur Universal Theatre at the "Falcon" Polish Gymnastic Society, with whom - according to Ciechowicz - until 1939, realized some 40 performances. ${ }^{8}$

The young Karol Wojtyla was associated with the Amateur Universal Theatre. When mentioning his first encounter with Kotlarczyk, Wojtyła wrote: "He was as a pioneer of the original theatre in the noblest sense of the word as the expressor of both the Polish and Christian traditions of art, which was conveyed to us by the entirety of our literature and, above all, by the great romantic and neoromantic literature." This marked the beginning of their long-term friendship. Under the influence of Kotlarczyk, the views of Karol Wojtyła on the importance of romantic culture and literature in the history of the Polish nation were shaped. Kotlarczyk was an intellectual partner for discussion, with whom Wojtyła shared insights on the Polish art, its place in the new reality, the mission of the theatre

${ }^{4}$ J. Kotlarczyk, J. Kotlarczyk-Mrozowa, D. Mróz-Krysta, Wadowickie teatry, teatrzyki i idee Mieczysława Kotlarczyka, „Wadoviana” (2015), no 18, pp.174-176; J. Ciechowicz, Dom opowieści. Ze studiów nad Teatrem Rapsodycznym Mieczysława Kotlarczyka, Gdańsk 1992, Wydawnictwo Uniwersytetu Gdańskiego, p. 11.

${ }^{5}$ S. Dziedzic, Rapsodyczny „płaszcz niewyżebrany”..., p. 124.

${ }^{6}$ J. Ciechowicz, Dom opowieści..., p. 11.

${ }^{7}$ J. Kotlarczyk, J. Kotlarczyk-Mrozowa, D. Mróz-Krysta, Wadowickie teatry..., pp. 177-179.

8 J. Ciechowicz, Dom opowieści..., p. 12.

${ }^{9}$ K. Wojtyła, Przedmowa do książki Mieczysława Kotlarczyka Sztuka żywego słowa, Rzym 1975, in: M. Kotlarczyk, K. Wojtyła, O Teatrze Rapsodycznym. 60-lecie powstania Teatru Rapsodycznego, preface and prepared by J. Popiel, selection of texts T. Malak, J. Popiel, Kraków 2001, The Ludwik Solski State Drama School, p. 295. 
artist and the role of the word. Stanisław Dziedzic wrote, "Common thoughts and exchange of artistic experiences served well this authentic friendship, and Karol, who was a regular guest in Kotlarczyk's house, was seen by the hosts virtually as part of the household." ${ }^{10}$

In contrast with his father's theatre, Mieczysław Kotlarczyk preferred a classical repertoire. In 1931 he also made his debut as a Theatre critic. Using the pseudonym of "Emka", he published theatre reviews, initially in the "Voice of the Nation", and in 1936 he undertook cooperation with the national-radical "Kuźnica", in which he posted reviews of performances staged in the Sosnowiec and Katowice theatres. Under his own name, Kotlarczykwould publish his discourses on the theatre in "Logeion".

In the summer of 1937 Kotlarczyk made a theatre trip to Salzburg, where he was watching stage set up by Max Reinhardt. Upon his return, Kotlarczyk made an artistic contact with Juliusz Osterwa, who offered him cooperation in the experimental "Reduta" theatre run by Osterwa. At that time, Kotlarczyk tried his hand as a playwright, writing two morality plays: "Everyman" ("Każdy") and "I am Polish" ("Jestem Polakiem") as well as the dramas "Discord" ("Zgrzyt") and the "Mob Scene" ("Zbiegowisko"). At that time he was at the peak ofactivity. In addition to all of the above, he also gave theatre talks at the Katowice and Kraków radio stations of the Polish Radio, studied the drama of Alexander Moissi and "The Technique of the Contemporary Language" by Juliusz Tenner, both of whom having exerted a significant influence on Kotlarczyk's artistic exploration. ${ }^{12}$

\section{The war reality}

In 1938, Kotlarczyk married Zofia Opidowicz, a student of the Polish studies. After the outbreak of World War II, he and his family moved to Wadowice, where they continued to live for two years. Kotlarczyk played an active role in the underground Polish Union of Country Defendersand co-edited the "Dla Ciebie Polsko" magazine. In the summer of 1941, fleeing from being arrested

10 S. Dziedzic, Romantyk Boży, Kraków 2014, Wydawnictwo M, p. 39.

11 J. Ciechowicz, Dom opowieści..., p. 12.

12 J. Ciechowicz, Dom opowieści..., p. 12; S. Dziedzic, Rapsodyczny „płaszcz niewyżebrany”..., p. 125. 
by the Gestapo, he found himself in Kraków. Together with his family, he stayed in the apartment of Karol Wojtyła, who, having graduated from high school in 1938 and having commenced studies at the Jagiellonian University, settled with his fatherat Tyniecka street in Kraków. ${ }^{13}$ Living under one roof undoubtedly contributed to the deepening of the friendship and artistic relationship of Karol Wojtyła and Mieczysław Kotlarczyk. Detachment and war experiences strengthened their friendship. Since the outbreak of the World War II, Wojtyła would write letters to Kotlarczyk, in which he shared his dreams of creating art and work. The correspondence was transported through the green border by Halina Królikiewicz (married name Kwiatkowska), who observed many years later, 'These letters mark the beginning of the Theatre of the Word', of which both of them had dreamed. ${ }^{14}$

At the beginning of November 1939, in a letter entitled "To Brother Mieczysław Protagonista at the Greek Theatrum", Wojtyła observed, "We have always perfectly understood each other. And today - this cataclysm could only bring us closer. We are those who argue first, who make a breakthrough in the ages and stand on the wandering rays." He shared his dreams of art, thanks to which a man would be able to "reach across this unfortunate threshold of knowing the good and evil and understand his way back to the Paradise, so that we would this once walk the theatre of life and see not the masks, but the Truth, the Divine Truth." ${ }^{15}$ Wojtyła declared his attachment to his friend: "I have always accompanied You, my Brother, as John the Apostle would accompany Peter, and Peter was a rock, and His Church was built on that very rock, and let this Theatre be His Church... and in it - in the congregation, in the assembly of the national art, the Spirit of the Nation; the one who longs and burns, but not hawks or peddles. ${ }^{\text {"16 }}$ According to Jacek Popiel, both this and other war letters of Wojtyła to Kotlarczyk illustrate the discussion between the two Wadowice friends, without which it would be difficult to understand the circumstances of the founding of the

13 S. Dziedzic, Rapsodyczny „płaszcz niewyżebrany”..., p. 125.

${ }^{14}$ H. Kwiatkowska, Porachunki z pamięcią, Kraków 2002, Oficyna Wydawnicza Kwadrat, p. 30 .

${ }^{15}$ Listy Karola Wojtyły do Mieczysława Kotlarczyka, in: M. Kotlarczyk, K. Wojtyła, O Teatrze Rapsodycznym...., p. 304.

${ }^{16}$ Listy Karola Wojtyły do Mieczysława Kotlarczyka, in: M. Kotlarczyk, K. Wojtyła, O Teatrze Rapsodycznym...., p. 304. 
Rhapsodic Theatre. ${ }^{17}$ According to Stanisław Dziedzic, these letters show that, for a young Wojtyła, Kotlarczyk was a "spiritual guide of a young, emerging artist, still seeking his artistic identity, and sometimes troubled by doubts: to choose theatre or rather dedicate himself to literary activity." 18

In Kraków, Kotlarczyk initially worked as a tram conductor, and from October 1942, as a clerk in the Krakow Chamber of Agriculture. Through Karol Wojtyła, he made contact withKraków’s delegation of the "Union" underground catholic organization, in which, together with the novelist and theatre critic Tadeusz Kudliński, they created a secret, amateur Rhapsodic Theatre. According to Jacek Popiel, "What determined the fate of a group of young people who tried to find meaning in life in difficult occupation conditions was the personality of Kotlarczyk." ${ }^{19}$ Popiel invoked Tadeusz Kudliński who, recalling the then difficulties, observed: "During the German occupation, we were a loose group brought together by the performances staged during the Kraków's Days of 1939, and now broken, despondent, not knowing what to do when thinking was forbidden. [...] We finally got to gathering, talking about the theatre, about different works from the great repertoire, to then, within the confined space of the four walls trying to play single scenes. During these works we would hear the young ones say: If only Dr. Kotlarczyk were here with us! [...] The young onescontinuously insisted and somehow, by means known only to themselves [...] the legendary Dr. Kotlarczyk was summoned to Kraków."20

Soon Kotlarczyk took over the care of the theatre. On 22 August 1941, he held the first programme meeting with his team. The team comprised of: Krystyna Dębowska (married name Ostaszewska), Halina Królikiewicz (married name Kwiatkowska), Danuta Michałowska, Tadeusz Ostaszewski, and Karol Wojtyła. ${ }^{21}$

The theatre launched its activity on 1 November 1941 with the premiere of "Król Duch" ("The Spirit King”) by Juliusz Słowacki, which was staged in the Kraków apartment of Krystyna Dębowska at ul. Komorowskiego. Danuta Michałowska would recall, "It was a truly unique experience both for us and for our audience. [...] This was about Słowacki, about the Polish word, about art

17 J. Popiel, Los artysty w czasach zniewolenia. Teatr Rapsodyczny 1941-1967, Kraków 2006, Wydawnictwo Uniwersytetu Jagiellońskiego, p. 27.

18 S. Dziedzic, Romantyk Boży..., p. 92.

19 J. Popiel, Los artysty..., p. 24.

${ }^{20}$ Cyt. za: J. Popiel, Los artysty..., p. 25.

${ }^{21}$ J. Popiel, Los artysty..., pp. 31-32. 
and about Polishness in general - we felt it all. [...] The candles, white chrysanthemums and the white face of the poet, looming in the faint flame against the dark curtain - and finally the underground circumstances, bonding everyone gathered in an overwhelming manner - it all made up a unique atmosphere, elevated and cordial, festive and family mood. [...] From the artistic point of view it was a well-balanced performance, of course, taking into account our youth and still unbalanced skills. However, it should be emphasized that the climax was the final fragment of [...] Bolesław Smiały in the interpretation of Karol Wojtyła. Neither before nor afterward had I ever heard him attain in this, or other passage, such wonderful expressions or such shocking dramatic experience. We who had participated in all rehearsals and knew every accent by heart - we would stand there, dumbfounded and enchanted." ${ }^{22}$

The premise of the theatre was the primacy of "a spoken and pure word", minimalist decoration, and the stage. Actors restricted gesticulation, focusing mainly on the verse. In the difficult occupation reality, regardless of the roundups and announcements of further executions, they would meet twice a week (on Wednesdays and Saturdays) in various apartments. ${ }^{23}$ Many years later, in his book "The Gift and mystery", Pope John Paul II recalled: "The recitations took place before a small group of people whom we knew, and before guests who, because they had a particular interest in literature, belonged in a sense to the "initiated". It was essential to keep these theatrical get-togethers secret; otherwise we risked serious punishment from the occupying forces, even deportation to the concentration camps. I must admit that the whole experience of the theatre left a deep impression on me, even though at a certain point I came to realize that this was not my real vocation." ${ }^{24}$

On the basis of the works of Polish poets: Adam Mickiewicz, Juliusz Słowacki, Zygmunt Krasiński, Cyprian Norwid, Aleksander Fredro, Stanisław Wyspiański, Jan Kasprowicz, and Karol Hubert Rostworowski, Kotlarczyk put up a spiritual resistance towards the German occupation, defended the dignity of national culture, showed the beauty of the word, carried hopes and warmed hearts of the Poles. Years later, Halina Kwiatkowska wrote, "We, the rhapsodists, like

22 D. Michałowska, Pamięć nie zawsze święta. Wspomnienia, Kraków 2004, Wydawnictwo Literackie, pp. 148-149.

23 J. Popiel, Karol Wojtyła i Mieczysław Kotlarczyk...., p. 278.

${ }^{24}$ John Paul II, Gift and mystery. On the fiftieth anniversary of my priestly ordination, New York 1996, p. 11. 
rhapsodies in ancient times with their song and word, keep up the spirit of the troubled Poles with our greatest national poetry, now forbidden by the Germans. I am confident about the need and sense of our activity and I do not fear. We secretly meet the audiences in the Krakow salons of brave friends, gathering and departing each of us separately." ${ }^{25}$

The Rhapsodic Theatre, operating under the patronage of the Government Delegation for Poland, was undoubtedly an important element of the underground cultural life in Kraków. During the occupation period there were seven premieres. ${ }^{26}$ Karol Wojtyła was involved in the theatre's work until mid-1943. Although he did not appear on the stage following his priestly ordination, his interest in the activities of the group never dwindled. The other rhapsodists, in turn, would accompany Father Wojtyła in important events in his priestly life. $^{27}$

\section{The post-war activity}

In the spring of 1945, the Rhapsodic Theatre emerged from the underground. Althougha decision to resume its activity was made at the beginning of that year, the relevant permission of the authorities was issued on 1st March. With Kotlarczyk having started work in the Department of Culture and Art of the Kraków Voivodship Office in February as a clerk in the theatre division, and then (until 1946) at the Board of Education of the Kraków School District, the application for permission to run thetheatre was submitted by the actor and composer Antoni Żuliński. ${ }^{28}$

The first season of the theatre's public activity was inaugurated on the 22 April with the premiere of the "Grunwald" play, based on excerpts from the works of Adam Mickiewicz ("Grażyna", "Konrad Wallenrod”) and Juliusz Słowacki (“Zawisza Czarny”)".

${ }^{25}$ H. Kwiatkowska, Porachunki z pamięcia..., p. 34.

${ }^{26}$ J. Popiel, Los artysty..., p. 35.

27 J. Popiel, Los artysty..., p. 279-280.

28 J. Popiel, Los artysty..., p. 43.

29 J. Popiel, Los artysty..., p. 42; J. Popiel, Wstęp, in: M. Kotlarczyk, K. Wojtyła, O Teatrze Rapsodycznym..., p. XII. 
The Rhapsodic Theatre continued its activity and, at first, enjoyed the favour of the authorities, and was even assigned a category of a school theatre, obligatory in education ${ }^{30}$. In March 1946, by way of the decision of the Main Board of the Association of Polish Stage Artists (ZASP), the theatre was recognized as a professional theatre, and the members of the staff received the professional status of actors and IDs of the ZASP (Association of Polish Stage Artists) full members or candidate members. ${ }^{31}$

Without renouncing his worldview, faith, political convictions, or artistic programme, the theatre run by Kotlarczyk amongst repression, aggression, evil, and lies of the first post-war years was a bastion of resistance against sovietization, oppression, destruction of national culture, and communist indoctrination.

The kindness of the authorities was, however, soon over. The character of the repertoire was increasingly seen as foreign and contradicting the then promoted socialist realism. In 1946, the resolution that granted the theatre the right to compulsory school education was cancelled and the theatre was expelled from the building of the "Wolność" cinema, in which it had found its temporary seat in the post-war period. Since September, the Rhapsodic Theatre has moved to the Groteska Puppet and Actor Theatre at ul. Skarbowa, where it was allowed to stage playstwice a week only. In the spring of 1947, the governor of Kraków, Kazimierz Pasenkiewicz, banned the Rhapsodic Theatre from using the said premises, describing its activities as "anti-social" and "anti-state." ${ }^{32}$ Then the Primate of Poland, Cardinal August Hlond came to its aid.

Thanks to the subsidy received from him, the premises at the Sisters of Mercy at ul. Warszawska, where previously the Iwo Gall's Studio, a renowned Kraków director, had been located, were granted. ${ }^{33}$ Thanks to Kotlarczyk's efforts, already since September 1946, the Dramatic Studio was already operating in the building, which was a kind of drama school. It operated until March 1953. Initially, the head of the school was Tadeusz Kudliński, and following his imprisonment in December 1948 by the communist Security Service, the studio was run by Mieczysław Kotlarczyk. The school's curriculum was tailored to individual aptitudes of the students and planned to be carried out within a period of one up to three years.

30 J. Ciechowicz, Dom opowieści..., p. 23.

${ }^{31}$ J. Ciechowicz, Dom opowieści..., p. 26; J. Popiel, Los artysty..., p. 50.

${ }^{32}$ M. Kotlarczyk, Reduta słowa. Kulisy dwu likwidacji Teatru Rapsodycznego w Krakowie (karty z pamiętnika), London 1980, Odnowa, p. 13.

33 J. Ciechowicz, Dom opowieści..., p. 31; J. Popiel, Los artysty..., p. 57. 
The goal of the Studio was "to work on the development of the rhapsodic style as a way of developing the overall Polish theatre style - and to raise youth for the purposes of the rhapsodic-like stage." ${ }^{34}$

At that time, the communist secret services were carrying out investigative operations against the members of the "Union". Some of its activists were arrested and the other ones were subjected to surveillance. ${ }^{35}$ The main collaborator of Kotlarczyk, Tadeusz Kudliński, was sentenced to 7 years of imprisonment in August 1950.

The Communist Security Service (UB) first took interest in Kotlarczyk in 1945. At the beginning of 1949, it intended to: "Expose a unionist activity [...] of the Theatre and of its head, Mieczysław Kotlarczyk. Effect discreet cessation of all state subsidies for this theatre and eventually lead to its self-liquidation. At the Theatre, recruit agentsto run a more thorough investigation of the team and management and secure [...] any preventive undertakings." ${ }^{36}$

Despite the unfavourable situation, thanks to the ability to win over people and his organizational skills, Kotlarczyk managed to convince Włodzimierz Sokorskithe then undersecretary of state at the Ministry of Culture and Art, one of the main promoters of the so-called socialist realism - to erect a new building that would house the theatre, because, among others, the Soviet theatre scientist Sergiusz Obrazcow was delighted with the adaptation of Kotlarczyk's "Eugene Onegin" by Alexander Pushkin, which he watched at a special show in November 1948. According to Jacek Popiel, the success of the play saved the director of the Rhapsodic Theatre from repression, and the opinion of Obrazcow became "an important argument in defense of Kotlarczyk against charges of the authorities and critics." ${ }^{37}$

In order for the Rhapsodic Theatre to survive in the Stalinist Poland, Kotlarczyk had to make some concessions to the authorities and avoided conflicts. In September 1952, at his request, regular ideological training courses were

34 As quoted in: J. Popiel, Los artysty..., p. 58.

35 The activities of the communist secret services towards the "Union" organization and the Rhapsodic Theatrehave been described by: D. Koczwańska-Kalita, „Nie ma narodupolskiego, kolegoKotlarczyk!” Walka komunistów z Teatrem Rapsodycznym, „Arcana” (2005), no 63, pp. 58-66; J. Popiel, Los artysty w czasach zniewolenia. Teatr Rapsodyczny 1941-1967, Kraków 2006: Wydawnictwo Uniwersytetu Jagiellońskiego.

36 The Archive of the Institute for National Remembrance Branch in Kraków [hereinafter AIPN Kr] 075/69, v. 2, The case codenamed „Dzwon” („The Bell”), Schedule for further works on the case codenamed “Dzwon”, Kraków 3 I 1949, c. 384.

37 J. Popiel, Los artysty..., pp. 67-68. 
conducted in the Theatre by the writer and party activist Adam Polewka. According to Jacek Popiel, "given the circumstance, the training was not only the implementation of the recommendations of party decision makers, but also an attempt to save the existence of the theatre." ${ }^{38}$

At the end of 1951, the Rhapsodic Theatre moved to a new headquarters at Starowiślna street (then Bohaterów Stalingradu street). A few weeks later, Kotlarczyk was notified that his Theatrehad to be liquidated owing to it "not being socialist realist". ${ }^{39}$ At the beginning of 1952, Kotlarczyk was dismissed from the post of director of the Theatre by way of a telegram. Following an intervention of Professor Leopold Infeld, world-renowned physicist, with the state authorities, the decision was temporarily suspended. ${ }^{40}$ The defense of Kotlarczyk and the Rhapsodic Theatre was taken up by Karol Wojtyła, in an article entitled "On the Theatre of the Word" published under the pseudonym of Piotr Jasien in "Tygodnik Powszechny". ${ }^{41}$ Soon, however, some misunderstanding in the friendly relations between Wojtyła and Kotlarczyk occurred. Thisstemmed from Wojtyła's critical remarks following the premiere of the play entitled "Polonez Imć Pana Bogusławskiego" ("The Polonaise of MrBogusławski”), of the manner of portraying the Church in the play. Kotlarczyk reacted strongly to the criticism, and for some time fell out with his friend. ${ }^{42}$

Despite the unfavourablecircumstances and the increased activity of the communist repression apparatus, the Rhapsodic Theatre continued its activity. In February 1953, during the National Theatre Congress in Warsaw, Kotlarczyk tried to defend the concept and ideals of his theatre: "The Rhapsodic Theatre is an ordinary and simple thing. For what is simpler than to muster a civic attitude to one's own speech, to the Polish language in its highest manifestations and in the years of the most heinous Nazi occupation, to remind of Poland using the words of its greatest poets! What is simplerthan, over these 12 years, to traverse all epochs of Polish literature, learn it and pass it on through the living word!"43

38 J. Popiel, Los artysty..., p. 88.

39 D. Koczwańska-Kalita, „Nie ma narodu polskiego, kolego Kotlarczyk!”..., p. 60.

40 J. Popiel, Los artysty..., p. 84.

${ }^{41}$ P. Jasień [real name K. Wojtyła], O teatrze słowa, „Tygodnik Powszechny” (1952), no 11 (16 III).

42 J. Popiel, Los artysty..., p. 282.

43 The speech of Mieczysław Kotlarczyk at the Theatre Congress in Warsaw on 17 February 1953, in: „...trzeba dać świadectwo” 50-lecie powstania Teatru Rapsodycznego w Krakowie, 
In his comment on the Kotlarczyk's statement, the then Minister of Culture and Art Włodzimierz Sokorski observed, "Kotlarczyk does not understand a thing and he has been stuck in the occupation period. The speech he has made was surprisingly backward and flagrant. And at the same time he was floating above our heads, above the party, above the government. He was appealing to the Polish nation! [...] There is no Polish nation, comrade Kotlarczyk! There is no Polish nation, I shall repeat, do remember this, there is only the working class!"44 Shortly thereafter, Kotlarczyk was dismissed from the position of director and artistic manager. He was also handed in the termination notice from the State Drama School, where he had been lecturing since the autumn of 1950. He was even stripped off his membership in the ZASP. At the same time, the Security Service was running a disruptive action against Kotlarczyk's team in order to break through its agents and the unity of the group. The last performance took place on 30 April 1953. The theatre ceased to exist for a few years. Throughout that time, Kotlarczyk undertook continuous efforts in order to reactivate the theatre. His attempts were to remain ineffective. In the autumn of 1954, he succeeded in undertaking employment as lecturer under contract in pronounciation at the Kraków State Drama School. At that time, he was also collaborating with Kraków's editorial office of the Polish Radio. ${ }^{45}$

\section{Reactived and liquidatedagain}

The Rhapsodic Theatre was reactivated only during the Polish thaw of October 1956. The group resumed their activity on 27 November 1957 with the premiere of the „Legendy złote i błękitne” (“Golden and Blue Legends”), i.e. a new adaptation of „Król-Duch” ("the Spirit King”) by Juliusz Słowacki. It is worth mentioning that the postulate to restore the theatre was one of the most important demands put forward within the area of culture during the thaw of October 1956 in Kraków. It did not manage to recover the stage at Starowiślna street, already taken over by the Old Theatre (StaryTeatr), nevertheless, supported by the city, the Theatre returned to Skarbowa street.

selected texts, comments and footnotes D. Michałowska, Kraków 1991, ArsNova - Zjednoczeni Wydawcy, p. 53.

${ }^{44}$ M. Kotlarczyk, Reduta słowa..., p. 29.

45 J. Ciechowicz, Dom opowieści..., pp. 54-55. 
While efforts to reactivate the theatre were being made, the Security Service attempted to recruit Kotlarczyk as an informer. The pursuits however remained unsuccessful. In June 1956 a registration and observation case against him was set up, taking as a basis the fact that during the occupation, as well as later and until 1948, he was a member of the "illegitimate Christian Democratic organization called the Union»." ${ }^{\prime 6}$ Ina few months the case was discontinued due to no evidence of any hostile activity. In 1959, however, it was decided that Kotlarczyk was capable of undertaking such activity and a registration and observation case codenamed "Łącznik" ("Liaison Officer") against him was re-established. Particular attention was paid to the theatrical work and Kotlarczyk's contacts with the church hierarchy, especially relations with the bishop, and then the archbishop of Kraków, Karol Wojtyła and Primate Stefan Wyszyński. All possible methods and operational measures were used. The case was brought to an end in the autumn of 1976 "due to the advanced age of the subject, his retirement and cessation of further professional and political activities." ${ }^{\text {"7 }}$

Earlier, however, the Rhapsodic Theatre had again been liquidated. On 22 April 1967, Zbigniew Skolicki, the chairman of the Presidium of the Municipal National Council in Kraków requested the Ministry of Culture and Art to dismiss Kotlarczyk "due to the failure of the latter to run the Theatre in accordance with the requirements and needs of the policy on culture issuesin the city of Kraków, and giving no guarantees that in the future this state of affairs would changeas expected." ${ }^{48}$

On 3 May 1967, the Presidium of the Municipal National Council issued a decision on the liquidation of the Theatre as of 1 September. According to Dorota Koczwańska-Kalita, this was an unofficial reaction of the authorities against Cardinal Wojtyła for his speeches during the celebration of the Millennium of the Baptism of Poland in $1966 .{ }^{49}$ The decision may as well have been influenced by the participation of Kotlarczyk in the Millennium celebrations in Częstochowa on 3 May 1966. One should bear in mind that any contact between Wojtyła and Kotlarczyk was seen by the secret services as evidence

46 AIPN Kr 010/1191, pdf, The "Łącznik" watch-and-record case, Summary of evidence against MieczysławKotlarczyk, Kraków 10 VIII 1959 r., p. 16.

${ }^{47}$ Ibidem, A note from the analysis of the evidentiary questionnaire for the "Łącznik" case Kraków 26 X 1976, p. 148.

48 J. Ciechowicz, Dom opowieści..., p. 91.

49 D. Koczwańska-Kalita, „Nie ma narodu polskiego, kolego Kotlarczyk!”..., p. 64. 
of anti-state activity. Many years later Kotlarczyk recalled that, when on $22 \mathrm{Au}$ gust 1966, on the occasion of the 25th anniversary of the existence of the Rhapsodic Theatre, Archbishop Karol Wojtyła celebrated the Holy Mass at Wawel "this episode of the Wawel's prayer, prayer for the good of institution, was considered an anti-state action, a crime equal to almost state treason, and a case resembling a scandal was made." 50

In making the decision to liquidate the Rhapsodic Theatre again, the authorities did not produce any substantive arguments, the sole reason submitted thereby being the need to secure the premises for the Groteska Theatre. None, however, was to be convinced by this reasoning. The person to step up in defence of the Rhapsodic Theatre and its director, was Archbishop Karol Wojtyła. In a letter of 9 June 1967, addressed to the minister of culture and art, Wojtyła emphasized "how serious a service did the Theatre fulfil towards the Polish culture. He recalled that the society felt the previous liquidation awrong done to the Polish culture, and the reactivation of the Theatre was considered right to remedy this wrong." Wojtyła believed his duty was to stand up for the Theatre. He wrote, "This is why I write to you, the Minister, one of the persons concerned about the announcement of another liquidation of the Rhapsodic Theatre, and removal of the distinguished founder and director thereof. I consider it my duty all the more that I was associated with forming of this Theatre during the difficult period of occupation. I am therefore convinced that the Minister should take my statement in this matter under consideration and repeal the decision of the Kraków's authorities." 51 This letter, similarly to the letter of the Main Board of the Polish Writers' Union, along with other appeals addressed to the authorities in the case at hand, remained unanswered. ${ }^{52}$ The decision of the authorities was final.

Once more Kotlarczyk had no employment. It was the Church who came to his aid, and especially Cardinal Karol Wojtyła. In the years 1967-1977, Kotlarczyk taught classes in rhetoric and pastoral phonetics at the Kraków Archdiocesan Seminary and the Franciscan Higher Seminary in Kraków. From 1967, Kotlarczyk also collaborated with the Catholic University of Lublin and the

${ }^{50}$ M. Kotlarczyk, Reduta słowa..., p. 138.

${ }^{51}$ Letter of Archbishop of Krakow Karol Wojtyła to the Minister of Culture and Art Lucjan Motyka Kraków 9 VI 1967 r., in: M. Kotlarczyk, K. Wojtyła, O Teatrze Rapsodycznym..., p. 334.

52 J. Popiel, Los artysty..., s. 157; D. Koczwańska-Kalita, „Nie ma narodu polskiego, kolego Kotlarczyk!”.., pp. 64-65. 
university's Academic Theatre. Until his death, he would unwaveringly believe in the possibility of reactivating the Rhapsodic Theatre. These hopes were to remainunfulfilled. Kotlarczyk died of a heart attack on 21 February 1978. Cardinal Karol Wojtyła escorted his master to the place of his eternal rest. On 25 February, a few hours before the funeral, in aletter to the widowed Zofia Kotlarczyk, he borne witness to his friendship with the deceased, saying in the letter: "I feel [...] the need to write to you not only to express my compassion after Mietek's death, but also because, to return to everything that brought us together-that brought to him, and thus to you and to your children. One does not easily let go of all this. What brought us together were the things we both loved. For me, these were youthful loves, for him - a mature choice of life vocation and a mission towards the Christian culture of the Nation. And although my own calling, given to me by God, took me away from these youthful loves that I shared with Mietek, this friendship and this relationship - the bond flowing from the same loves - left in me a particularly cultivated layer of inner soil, which remains alive. I think I am compelled to write this to you as Mietek has died and on the day of his funeral I have to tell everyone about it." ${ }^{53}$

Danuta Michałowska recalled that in his funeral speech Cardinal Wojtyła spoke about Kotlarczyk as "the man who fought for Polishness, fought for the Polish language, Polish culture, Polish literature, and was destroyed by the regime. And all of this was put in harshwords." 54

Having already been elected the Pope, Karol Wojtyła on many occasions wrote and talked about his friendship with Kotlarczyk and the headstrong attitude of the latter. Wojtyła emphasized how important a role the Rhapsodic Theatre played in his life. Jacek Popiel observed that it would be difficult to imagine the biography of John Paul II "without pursuing the Polish studies, underground Rhapsodic Theatre, friendship with Mieczysław Kotlarczyk and without theideas nascent in Kraków, where the world of art amalgamated with the world of the spirit, and the world of the spirit with the world of art." ${ }^{35}$

${ }^{53}$ Listy Karola Wojtyły do Zofii Kotlarczyk, w: M. Kotlarczyk, K. Wojtyła, O Teatrze Rapsodycznym..., p. 335.

${ }^{54}$ An interview with DanutaMichałowska conducted by The Centre for the Thought of John Paul II http://www.centrumjp2.pl/wikijp2/index.php?title=Mieczys\%C5\%82aw_Kotlarczyk (3.08.2018) See D. Michałowska, Pamięć nie zawsze święta..., p. 339.

55 J. Popiel, Los artysty..., p. 287. 


\section{Bibliography}

AIPN Kr 010/1191, pdf, The record-and-watch case codenamed "Lącznik" ("The Liaison Officer").

AIPN Kr 075/69, v. 2, The subject case codenamed „Dzwon” („The Bell”).

Ciechowicz J., Dom opowieści. Ze studiów nad Teatrem Rapsodycznym Mieczysława Kotlarczyka, Gdańsk 1992.

Dziedzic S., Rapsodyczny „płaszcz niewyżebrany” Mieczysława Kotlarczyka, „Annales Universitatis Paedagogicae Cracoviensis. Studia Historico litteraria 12”, Kraków 2012.

Dziedzic S., Romantyk Boży, Kraków 2014.

Jan Paweł II, Dar i tajemnica, image 2, Kraków 2005.

Jasień P. [real name K. Wojtyła], O teatrze słowa, „Tygodnik Powszechny” (1952), no 11 (16 III).

Koczwańska-Kalita D., „Nie ma narodu polskiego, kolego Kotlarczyk!” Walka komunistów $z$ Teatrem Rapsodycznym, „Arcana” (2005), no 63.

Kotlarczyk M., Reduta słowa. Kulisy dwu likwidacji Teatru Rapsodycznego w Krakowie (karty z pamiętnika), Londyn 1980.

Kotlarczyk M., Wojtyła K., O Teatrze Rapsodycznym. 60-lecie powstania Teatru Rapsodycznego, preface and selection of texts by J. Popiel, selectedtexts T. Malak, J. Popiel, Kraków 2001.

Kotlarczyk J., Kotlarczyk-Mrozowa J., Mróz-Krysta D., Wadowickie teatry, teatrzyki i idee Mieczysława Kotlarczyka, „Wadoviana” (2015), no 18.

Kotlarczyk S., ....Z doby dzisiejszej. Za Matkę Ojczyznę, Wadowice 2007.

Kowalewski S., Apostoł Żywego Słowa, „Niedziela” (2003), no 9.

Kwiatkowska H., Porachunki z pamięcią, Kraków 2002.

Malak T., Karol Wojtyła a TeatrRapsodyczny, „Ethos”, R. 20, no 1/2 (2007).

Michałowska D., Pamięć nie zawsze święta. Wspomnienia, Kraków 2004.

Popiel J., Karol Wojtyła i Mieczysław Kotlarczyk. Historia artystycznej przyjaźni, „Ethos”, v. 20, no $1 / 2$ (2007).

Popiel J., Los artysty w czasach zniewolenia. Teatr Rapsodyczny 1941-1967, Kraków 2006.

„...trzeba dać świadectwo” 50-lecie powstania Teatru Rapsodycznego w Krakowie, selection of texts, comments and footnotes by D. Michałowska, Kraków 1991.

An interview with DanutaMichałowska conducted by The Centre for the Thought of John Paul II, http://www.centrumjp2.pl/wikijp2/index.php?title=Mieczys\%C5\%82aw_Kotlarczyk (13.08.2018). 